\title{
PELATIHAN PEMBUATAN PUPUK ORGANIK CAIR (POC) DARI SAMPAH ORGANIK RUMAHTANGGADENGAN METODE KOMPOSTER SEDERHANA DI DESA H. WUKIRSARI KECAMATAN TUGUMULYO
}

\author{
Yunita Wardianti, Yuni Krisnawati \\ Prodi Pendidikan Biologi STKIP PGRI Lubuklinggau \\ E-mail:yunita.wardianti13@gmail.com
}

\begin{abstract}
Wukirsari is a village located in Tugumulyo District, Musi Rawas Regency, South Sumatra, Indonesia, where most of the people work as farmers. The training on making liquid organic fertilizer was chosen in order to reduce household organic waste/waste which if not processed properly will cause environmental pollution and disturb the comfort of the community. Liquid organic fertilizer is the product chosen to be produced from this activity because liquid organic fertilizer has many advantages and benefits. Problems faced by partners such as the problem of household organic waste that pollutes the environment and disturbs the comfort of residents, this happens because the community does not understand how to process it, besides the lack of community knowledge and skills in making liquid organic fertilizer, even though liquid organic fertilizer has many benefits Therefore, it is necessary to conduct training activities on the manufacture of liquid organic fertilizer based on household organic waste. The method used is starting from preparation, socialization, and training. So it is expected that the output will be in the form of increasing knowledge and skills of the community in making liquid organic fertilizer, and creating products. The result of this activity is the implementation of socialization activities so that there is an increase in partner knowledge with an $N$-Gain value of 0.8 in the high category. In addition, the implementation of training activities on the manufacture of liquid organic fertilizers that provide partners' skills in making liquid organic fertilizers with a value of 92.9 in the very good category and the creation of products in the form of ready-to-use liquid organic fertilizers.
\end{abstract}

Keywords: organic liquid fertilizer, household waste, simple composter

\begin{abstract}
Abstrak
Wukirsari adalah desa yang terletak di Kecamatan Tugumulyo, Kabupaten Musi Rawas, Sumatera Selatan, Indonesia yang sebagian besar masyarakatnya berprofesi sebagai petani. Pelatihan pembuatan pupuk organik cair dipilih guna untuk mengurangi sampah/limbah organik rumah tangga yang jika tidak diolah dengan tepat akan menyebabkan pencemaran lingkungan dan mengganggu kenyamanan masyarakat. Pupuk organik cair menjadi produk yang dipilih untuk diproduksi dari kegiatan ini karena pupuk organik cair memiliki banyak keuntungan dan manfaat. Permasalahan yang dihadapi mitra seperti permasalahan sampah organik rumah tangga yang mencemari lingkungan dan mengganggu kenyamanan warga, hal ini terjadi karena masyarakat kurang paham dalam mengolahnya, selain itu kurangnya pengetahuan dan keterampilan masyarakat dalam membuat pupuk organik cair, padahal pupuk organik cair memiliki banyak manfaat. Oleh karena itu perlu dilakukan kegiatan pelatihan pembuatan pupuk organik cair berbahan dasar sampah organik rumahtangga. Adapun metode yang dilakukan yaitu dimulai dari persiapan, sosialisasi, dan pelatihan. Sehingga diharapkan diperoleh luaran berupa peningkatan pengetahuan dan keterampilan masyarakat dalam membuat pupuk organik cair, dan terciptanya produk,. Hasil dari kegiatan ini yaitu terselenggaranya kegiatan sosialisasi sehingga terdapat peningkatan pengetahuan mitra dengan nilai $N$-Gain sebesar 0,8 dengan kategori tinggi. Selain itu juga terselenggaranya kegiatan pelatihan pembuatan pupuk organik cair yang memberikan adanya keterampilan mitra dalam membuat pupuk organik cair dengan nilai 92,9 dengan kategori sangat baik dan terciptanya produk berupa pupuk organik cair siap pakai.
\end{abstract}

Kata kunci:, pupuk cair organik, sampah rumah tangga, komposter sederhana 


\section{PENDAHULUAN}

Desa Wukirsari terletak di Kecamatan Tugumulyo, Kabupaten Musi Rawas, Sumatera Selatan, Indonesia dengan jumlah penduduk mencapai 14.000 jiwa. Pekerjaan masyarakat Desa Wukirsari yang paling dominan adalah petani. Di Desa Wukirsari pernah dilakukan kegiatan pelatihan pembuatan kompos dari sampah organik rumah tangga dengan metode takakura. Berdasarkan hasil kegiatan tersebut diperoleh hasil berupa peningkatan pengetahuan dan keterampilan mitra dalam pembuatan pupuk kompos dengan metode takakura (Wardianti, 2020). Selain itu antusiasme warga dalam kegiatan pelatihan tersebut sangat tinggi dan berdasarkan permintaan dari mitra maka tim pengabdian kepada masyarakat melakukan kegiatan pelatihan tentang pembuatan pupuk organik cair brebahan dasar limbah rumahtangga. Warga sangat mendukung kegiatan yang pernah dilakukan. Bahkan warga meminta kepada tim pengabdian kepada masyarakat untuk melakukan kegiatan pelatihan-pelatihan yang lain seperti pembuatan pupuk cair organik. Dari Wawancara yang dilakukan oleh tim kepada mitra diperoleh informasi bahwa mitra sangat merasakan dampak positif dari kegiatan yang telah dilakukan karena dengan kegiatan tersebut mitra menjadi paham dan mampu membuat pupuk kompos sendiri dengan biaya yang murah dan dapat mengurasi sampah organik yang ada disekitar tempat tinggalnya.

Pelatihan pembuatan pupuk organik cair dipilih guna untuk mengurangi sampah/limbah organik rumah tangga yang jika tidak diolah dengan tepat akan menyebabkan pencemaran lingkungan dan mengganggu kenyamanan masyarakat. Pupuk organik cair menjadi produk yang dipilih untuk diproduksi dari kegiatan ini Karena pupuk organik cair memiliki banyak keuntungan dan manfaat.Adapun keunggulan dari pupuk organik cair salah satunya yaitu Pupuk cair lebih mudah terserap oleh tanaman karena unsur- unsur di dalamnya sudah terurai. Kelebihan dari pupuk cair adalah kandungan haranya bervariasi yaitu mengandung hara makro dan mikro, penyerapan haranya berjalan lebih cepat karena sudah terlarut, (Hadisuwito, 2007). Selain itu keunggulan dari pupuk organik cair berdasarkan penelitian Basmal (2010) adalah mengandung unsur hara makro dan mikro yang lengkap. Unsur hara makro pada pupuk organik cair lebih sedikit bila dibandingkan dengan pupuk anorganik/kimia, namun pupuk organik cair mengandung senyawa-senyawa yang tidak dimiliki oleh pupuk kimia seperti auksin, sitokinin (zeatin dan kinetin), dan giberelin yang berperan sangat optimal dalam mempercepat pertumbuhan tanaman. Pupuk organik cair juga berperan dalam meningkatkan kelembaban tanah, sehingga sangat cocok untuk daerah yang kelembaban tanahnya rendah. Selain itu, pupuk organik tidak merusak struktur tanah dan tetap mempertahankan unsur hara tanah. Pupuk organik cair juga lebih mudah diaplikasikan. Pupuk organik cair dapat diaplikasikan ke daun dan disiramkan ke media tanam.

Pupuk organik cair juga sudah terbukti mampu meningkatkan metobolisme tanaman sehingga berdampak pada pertumbuhan dan produksi tanaman. Seperti penelitian yang dilakukan oleh Marpaung (2017) yang menunjukkan hasil Pemberian POC krinyu dan kotoran kelinci yang memberikan dampak peningkatan pertumbuhan dan produksi tanaman kubis, pemberian POC krinyu dengan dosis $20 \mathrm{ml} / \mathrm{l}$ air dapat meningkatkan bobot tanaman, dan pemberian POC kotoran kelinci dengan dosis $10 \mathrm{ml} / \mathrm{l}$ air dapat meningkatkan diameter krop. Selain meningkatkan pertumbuhan dan produksi tanaman, pupuk organik cair juga dapat meningkatkan serapan nitrogen dan memperbaiki tanah. Seperti hasil penelitian Febriana (2018) yang memberikan hasil pemberian pupuk organic cair dengan dosis $100 \%$ dan diberikan 4 hari sekali dapat meningkatkan serapan nitrogen tanaman sawi sebesar 23,80\% apabila dibandingkan dengan perlakuan lain, dan pemberian pupuk organik cair pada tanah berpasir dapat meningkatkan keasaman (pH) tanah 14,31\%, C-Organik, dan $\mathrm{N}$ total tanah 62,97\%).

Dengan adanya kegiatan ini diharapkan mampu mengurangi jumlah sampah/limbah organik rumahtangga yang dapat mencemari lingkungan dan dapat memberikan pengetahuan dan keterampilan bagi mitra untuk mampu memproduksi pupuk organik cair yang kaya manfaat dan dapat digunakan untuk memupuk tanaman bagi masyarakat. Seperti halnya kegiatan yang dilakukan oleh Handayani (2019) yang memberikah hasil menumbuhkan kesadaran masyarakat 
Vol.2, No.1 Juni 2021

akan pentingnya hidup sehat dan kreatif, memotivasi masyarakat agar tidak mendekati pestisida dan pupuk kimia dan beralih kepada pupuk organik cair (POC).

Berdasarkan uraian yangtelah disampaikan, maka dapat dirumuskan beberapa permasalahan yang dihadapi oleh mitra. Adapun permasalahan yang dihadapi mitra yaitu Limbah/sampah organik rumahtangga yang mencemari lingkungan jika tidak diolah dengan benar akan mengganggu kenyamanan masyarakat, masyarakat memiliki program penanaman Tanaman Obat Keluarga (TOGA) dan menanam tanaman hias namun untuk pemupukan selain hanya menggunakan kompos untuk penyiraman hanya menggunakan air biasa dan belum memproduksi pupuk daun sendiri, dan kurangnya pemahaman dan keterampilan dalam mengolah sampah organik menjadi pupuk organik cair.

\section{SOLUSI DAN TARGET LUARAN}

Solusi yang ditawarkan untuk memecahkan permasalahan mitra yaitu sosialisasi, pelatihan, dan pendampingan. Sosialisasi dilakukan dengan menyampaikan materi tentang sampah organik dan pengolahannya, serta sosialisasi tentang manfaat pupuk organik cair bagi tanaman dan keunggulan pupuk organik cair. Dengan dilakukannya sosialisasi tersebut diharapkan masyakarat memiliki pengetahuan tentang pengolahan sampah organik. Selain itu juga dilakukan pelatihan pengolahan sampah organik rumah tangga menjadi pupuk organik cair yang bertujuan untuk menciptakan masyarakat yang terampil dalam membuat pupuk organik cair. Dansolusi berikutnya yaitu pendampingan pembuatan produk berupa pupuk organik cair yang siap untuk digunakan sehingga tercipta produk yang dap[at dimanfaatkan dalam budidaya tanaman..

\section{METODE PELAKSANAAN}

Tim pengabdian pada masyarakat melaksanakan kegiatan ini dengan tahapan persiapan dan pelaksanaan. Tahap persiapan dilakukan dengan observasi lokasi dan koordinasi dengan Kepala Desa Wukirsari yang merupakan pimpinan dari mitra pada kegiatan ini. Tahap pelaksanaan dilakukan dengan sosialisasi dan pelatihan.

a. Sosialisasi dilakukan untuk memberikan pengetahuan kepada mitra terutama ibu-ibu rumah tangga dengan materi sampah organik dan pengolahannya, serta sosialisasi tentang manfaat pupukorganik cair bagi tanaman dan keunggulan pupuk organik cair. Sosialisasi ini dilakukan dengan metode ceramah, tanya jawab dan diskusi.

b. Pelatihan dilakukan untuk memberikan bekal berupa keterampilan pembuatan pupuk organic cair kepada mitra terutama ibu-ibu rumah tangga. Pelatihan dimulai dengan merancang alat dan mempersiapkan bahan yang digunakan, membuat molase dan mencampurkannya dengan EM4, melakukan fermentasi sampah organic menjadi pupuk organic cair, dan aplikasi pemberian pupuk organik cair pada tanaman. Adapun bahan yang diperlukan dalam kegiatan ini yaitu sampah organik rumah tangga, EM4, pupuk kandang, air cucian beras, urin ternak seperti urin sapi atau kambing, dan molase. Alat yang digunakan dalam proses pembuatan pupuk organik cair yaitu tong komposer, ember, selang, karung, dan pengaduk. Langkah yang dapat dilakukan dalam membuat pupuk organik cair yaitu sebagai berikut. Siapkan bak komposter sebagai tempat pembuatan pupuk organik cair. Kemudian masukkan bahan baku berupa sampah organik rumah tangga. Sampah yang masih berukuran besar harus dicacah agar mempercepat proses pembusukkan dan dapat berlangsung sempurna. Selanjutnya disiapkan cairan bioaktivator EM4 (effective microorganisms) yang berfungsi sebagai bahan yang mempercepat proses penguraian sampah organik, Sebanyak 5-15 ml EM4 dicampur dengan $500 \mathrm{~mL}$ air sungai untuk bahan baku sebanyak $3 \mathrm{~kg}$. Sampah yang sudah di kumpulkan dan dicacah kemudian dimasukkan ke dalam tong komposter, lalu disemprot dengan cairan bioaktvator sampai merata ke seluruh bahan baku dan tong komposter ditutup rapat. Volum bioaktivator dapat ditambahkan pada hari ke 7 sambil diaduk dan melihat apakah pupuk organik cair sudah terbentuk. Biasanya pupuk organik cair hasil fermentasi akan terbentuk setelah 15-17 hari 
(Nur. 2016). Ciri dari pupuk organik cair sudah terbentuk dan siap digunakan adalah memiliki aroma yang khas seperti aroma fermentasi dan berwarna kecoklatan.

c. Evaluasi pelaksanaan kegiatan dilakukan selama proses pengabdian kepada masyarakat berlangsung untuk mengetahui apakah program berjalan dengan baik dan sesuai. Evaluasi pelaksanaan program dilakukan dengan memantauan kerja sama mitra dalam kegiatan sosialisasi dan pelatihan, pengecekan kelengkapan peralatan dan kemelimpahan bahan baku pembuatan pupuk organik cair, penyediaan tempat kegiatan serta pemantauan proses pembuatan pupuk organik cair, dan evaluasi terhadap pengetahuan yang dilakukan dengan pemberian pre-test dan post-test, serta evaluasi keterampilan mitra dengan dilakukannya pengamatan terhadap mitra selama kegiatan berlangsung. Evaluasi keberlanjutan program dilakukan setelah kegiatan sosialisasi dan pelatihan selesai dilaksanakan, dan evaluasi keberlanjutan program dilakukan sampai mitra mampu membuat pupuk organik cair sendiri dengan baik tanpa harus didampingi oleh tim pelaksana.

\section{HASIL DAN PEMBAHASAN}

Hasil yang diperoleh dari kegiatan pegabdian kepada masyarakat ini adalah terselenggaranya kegiatan sosialisasi tentang sampah organik dan pengolahannya, serta sosialisasi tentang manfaat pupukorganik cair bagi tanaman dan keunggulan pupuk organik cair. Selama kegiatan sosialisasi dilakukan antusiasme mitra sangan baik dalam mengikuti kegiatan ini. Sebelum pemateri menyampaikan materi sosialisasi, terlebih dahulu dilakukan pre-test dan di akhir keiatan sosialisasi juga dilakukan post-test. Pre-test dilakukan untuk mengetahui sejauh mana pemahaman mitra tentang sampah organik dan Pupuk Organik Cair sebelum dilakukan sosialisasi. Sedangkan post-test dilakukan untuk mengetahui pemahaman peserta didik setelah diberi materi dan dilakukannya kegiatan sosialisasi. Analisis dilakukan terhadap pengetahuan mitra sebelum dan sesudah dilakukan sosialisasi melalui pre-test dan post-test. Analisis ini betujuan untuk mengetahui apakah ada peningkatan terhadap pengetahuan mitra setelah sosialisasi dilakukan. Setelah dianalisis diperoleh hasil yang dapat dilihat pada tabel dibawah ini.

Tabel 1. Analisis pengetahuan mitra

\begin{tabular}{ccccc}
\hline Responden & \multicolumn{2}{c}{ Rerata } & Selisih & N-Gain \\
\cline { 2 - 3 } Mitra & 37,8 & 87,8 & 50 & 0,8 \\
\hline
\end{tabular}

Nilai N-Gain sebesar 0,8 berarti terdapat peningkatan pengetahuan yang dimiliki oleh mitra, dan peningkatan pengetahuan yang terjadi pada mitra tersebut termasuk dalam tingkatan yang tinggi. Perbandingan nilai rata-rata pengetahuan mitra sebelum dan sesudah kegiatan sosialisasi dapat dilihat pada gambar 1. Dari gambar terlihat bahwa rata-rata pre-test dan posttest mitra berbeda. Dan setelah dianalisis menunjukkan adanya peningkatan yang tinggi. Hal ini menunjukkan setelah dilakukan kegiatan sosialisasi dan mitra memperoleh materi tentang sampah organik dan pengolahannya serta manfaat pupuk organik cair, pengetahuan mitra meningkat dan semakin baik serta memahami tentang materi yang disampaikan. 


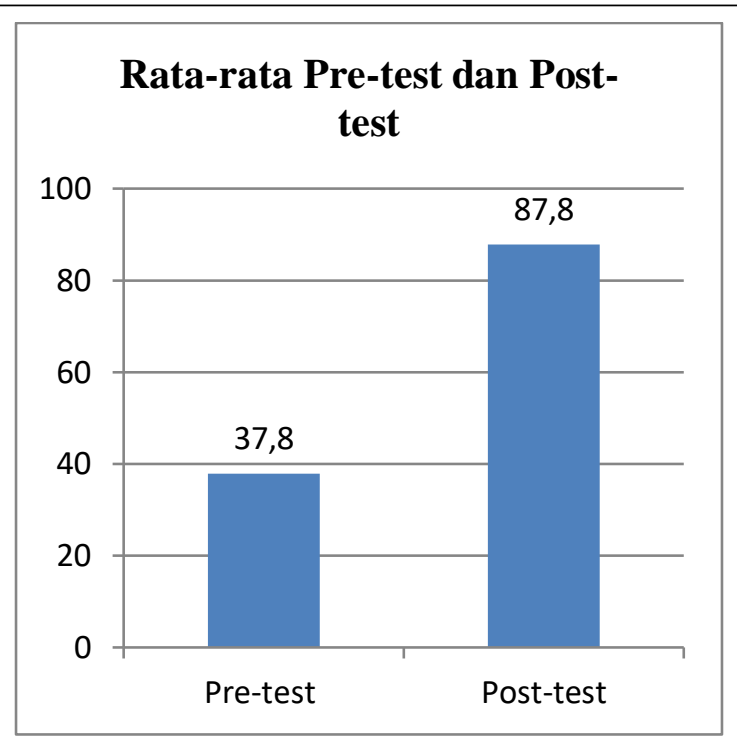

Gambar 1. Grafik rata-rata nilai pre-test dan post-test pengetahuan mitra

Peningkatan pengetahuan yang terjadi pada mittra, sehingga mitra memiliki pengetahuan yang tinggi tentang maateri yang disampaikan saat sosialisasi menunjukkan bahwa mitra ikut berpartisipasi pada kegiatan sosialisasi dengan baik. Hal ini juga menunjukkan bahwa sosialisasi yang dilakukan memberikan dampak positif terhadap mitra. Seperti kegiatan yang dilakukan oleh Surtiningsih (2018) yaitu pelatihan pembuatan pupuk organik cair pada kelompok tani di Kabupaten Probolinggo yang mununjukkan hasil terdapat peningkatan wawasan dan pengetahuan kelompok tani terkait pupuk

organik cair dan pembuatannya. Dari kegiatan yang dilakukan, proses sosialisasi dapat meningkatkan wawasan dan pemahaman kelompok tani. Sebesar 77\% kelompok tani memahami cara pembuatan pupuk organik cair.

Terselenggaranya kegiatan pelatihan dan pendampingan pembuatan pupuk organik cair yang memberikan hasil berupa keterampilan yang dimiliki oleh mitra dalam membuat pupuk organik cair dengan metode komposter sederhana. Analisis keterampilan mitra dilakukan selama kegiatan pelatihan dan pendampingan dengan melakukan pengamatan terhadap mitra. Setelah dilakukan analisis, diperoleh hasil bahwa rata-rata keterampilan mitra setelah dilakukan kegiatan pelatihan adalah 92,9 dan termasuk dalam kategori sangat baik. Dari hasil analisis yang dilakukan, selain peningkatan pengetahuan, mitra juga memiliki keterampilan dalam membuat pupuk organik cair. Hal serupa juga terlihat dari kegiatan yang dilakukan oleh Syafri (2017) yaitu pelatihan pembuatan pupuk organik cair bagi kelompok tani Desa Kartama Pekanbaru yang menunjukkan hasil tingkat pengetahuan dan keterampilan para peserta, umumnya mengalami peningkatan. Peserta merasakan hasil pengetahuan yang diperoleh sangat membantu untuk mengurangi biaya pembelian pupuk sekaligus dapat dikembangkan menjadi usaha rumah tangga. Berikut adalah foto kegiatan sosialisasi dan pelatihan yang dilakukan oleh tim pengabdian pada masyarakat. 


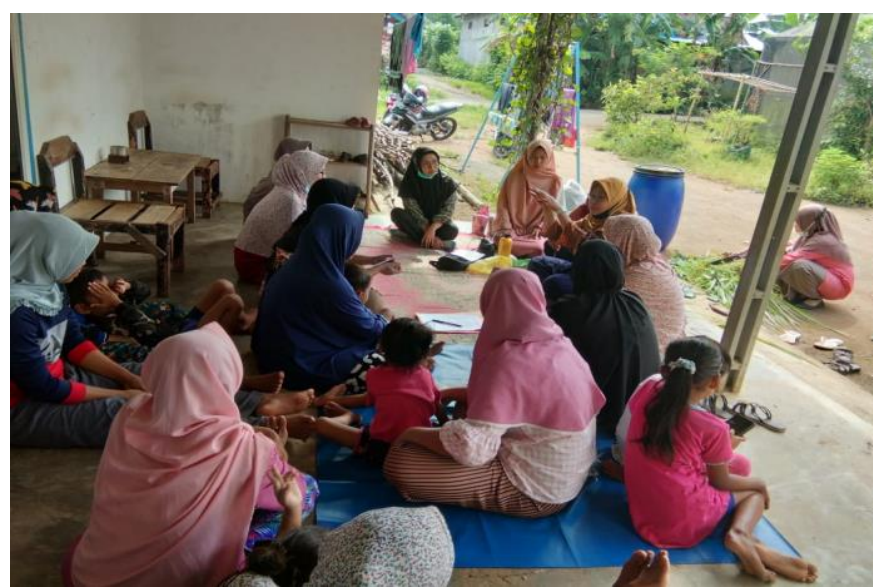

Gambar 2. Kegiatan sosialisasi

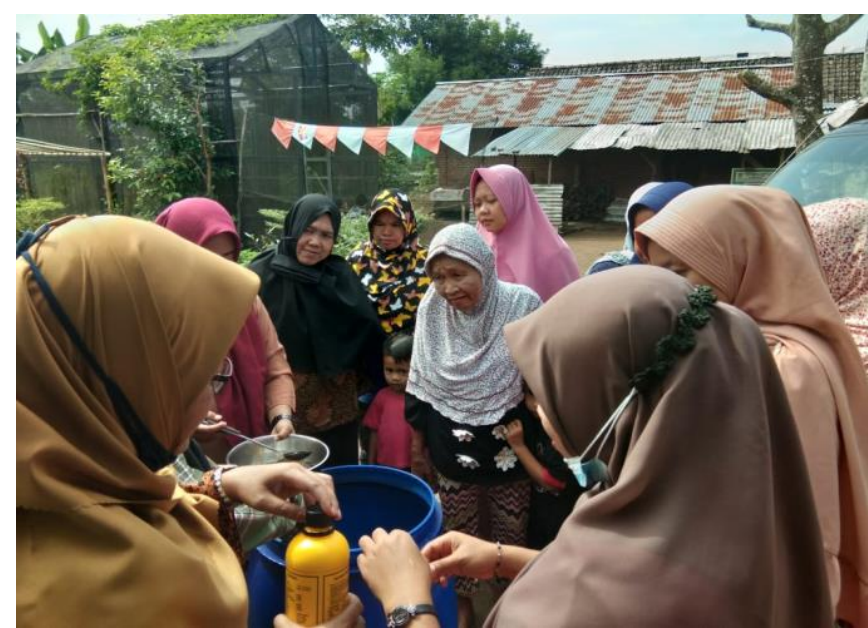

Gambar 3. Kegiatan pelatihan pembuatan pupuk organik cair

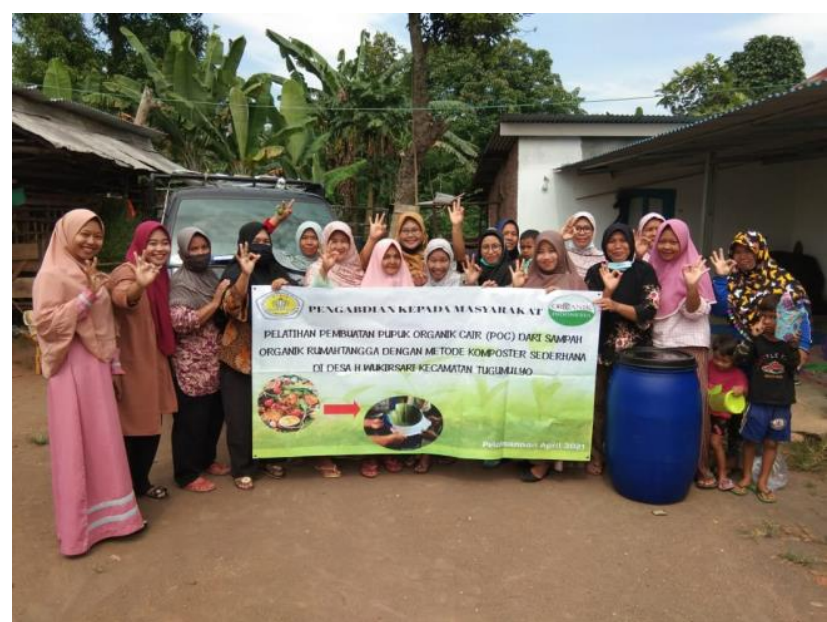

Gambar 4. Foto bersama peserta kegiatan pengabdian pada masyarakat.

Terbentuknya suatu produk berupa pupuk organik cair yang dapat digunakan sebagai penambah unsur hara dengan cara penyiraman ataupun penyemprotan pada tanaman. Pupuk organik cair yang diproduksi sangat menunjang program desa yaitu penenaman TOGA. Selain itu pupuk organik cair yang dihasilkan juga sangat mendukung program pertanian organik yang tidak menggunakan pupuk kimia sintetik. pupuk organik cair yang dihasilkan memiliki unsur hara 
makro dan mikro yang dibutuhkan tanaman. Walaupun belum diuji di Laboratorium, dengan penambahan EM4 dan menggunakan bahan baku berupa sampah organik rumahtangga yang dalam kondisi baik, maka pupuk organik cair yang dihasilkan akan mengandung beberapa unsur hara yang dibutuhkan tanaman. Penelitian yang dilakukan Nur (2016) tentang pembuatan pupuk organik cair dari sampah organik rumah tangga dengan penambahan bioaktivator EM4 (Effective Microorganisms) memberikan hasil bahwa proses pembuatan pupuk organik cair dengan variasi waktu dan variasi penambahan volume EM4 efektif dalam meningkatkan kandungan N, P, dan C. Semakin lama proses pembuatan pupuk organik cair (pengomposan) akan meningkatkan kandungan N, P, dan C dalam sampel lindi yang dihasilkan dan Penambahan volume EM4 akan meningkatkan kandungan $\mathrm{N}, \mathrm{P}$, dan $\mathrm{C}$ secara fluktuatif.

\section{SIMPULAN}

Dari kegiatan pengabdian pada masyarakat yang telah dilakukan dapat disimpulkan bahwa dengan terselenggaranya kegiatan sosialisasi dapat meningkatkan pengetahuan mitra dengan nilai N-Gain sebesar 0,8 yang berarti peningkatan pengetahuan termasuk kategori tinggi. Terselenggaranya kegiatan pelatihan pembuiatan pupuk organik cair yang memberikan keterampilan kepada masyarakat dalam membuat pupuk organik cair dengan nilai rata-rata 92,9 dan termasuk dalam kategori sangat baik. selain itu dari kegiatan pengabdian masyarakat ini juga terbentuk suatu produk berupa pupuk organik cair yaang dapat digunakan dalam budidaya tanaman.

\section{PERSANTUNAN}

Tim pengabdian masyarakat mengucapkan terimakasih kepada STKIP PGRI Lubuklinggau yang telah membiayai dan mendukung kegiatan pengabdian pada masyarakat. Tim pengabdian masyarakat juga mengucapkan terimakasih kepada kepala desa, staf, dan warga Desa Wukirsari atas partisipasi dan antusiasmenya.

\section{REFERENSI}

Basmal, J. 2010. Teknologi Pembuatan Pupuk Organik Cair Kombinasi Hidrolisat Rumput Laut Sargassum sp. Dan Limbah Ikan.Squalen. 5. (2). 59-66

Febrianna, M., dkk.2018. Pemanfaatan Pupuk Organik Cair untuk Meningkatkan Serapan Nitrogen serta Pertumbuhan dan Produksi Sawi (Brassica juncea l.)Pada tanah berpasir.Jurnal Tanah dan

Sumberdaya Lahan 5. (2). 1009-1018

Hadisuwito, S. 2007. Membuat Pupuk Kompos Cair. PT Agromedia Pustaka. Jakarta.

Handayani, L., dkk. 2019. Pelatihan Pembuatan Pupuk Organik Cair (POC) dari Limbah Dapur bagi Ibu-Ibu Desa Paya Kecamatan Trienggadeng Kabupaten Pidie Jaya. JURNAL ABDIMAS BSI Jurnal Pengabdian Kepada Masyarakat. 2. (2). 359-365

Marpaung, A.E. 2017. Pemanfaatan Jenis Dan Dosis Pupuk Organik Cair (Poc) Untuk Meningkatkan Pertumbuhan Dan Hasil Sayuran Kubis.Jurnal Agroteknosains. 1 (2). 117-123

Nur, T., dkk. 2016. Pembuatan Pupuk Organik Cair Dari Sampah Organik Rumah Tangga Dengan Penambahan Bioaktivator EM4 (Effective Microorganisms). Konversi. 5 (2). 5-12

Surtiningsih, T., dkk. 2018. Pelatihan Pembuatan Pupuk Organik Cair Pada Kelompok Tani di Kabupaten Probolinggo. Jurnal Layanan Masyarakat Universitas Airlangga. 02 (01). 21-24

Syafri, R., dkk. 2017. Pelatihan Pembuatan Pupuk Organik Cair Bagi Kelompok Tani Desa Kartama Pekanbaru. JURNAL Untuk Mu negeRI. 1. (1). 13-18

Wardianti, Y., Krisnawati. Y. 2020. Pelatihan Pembuatan Kompos dari Sampah Organik Rumahtangga dengan Metode Takakura.JURNAL CEMERLANG: Pengabdian pada Masyarakat. 3. (1). 1-11 